\title{
原著論文
}

\section{開発した薬動力学シミュレータの評価と 新しい吸入麻酔薬セボフルレン解析への応用}

三条芳光* 池田和之*

要旨 実データとのリンク・X·Y プロッタ出力等の特徴を持った薬動力学シミュレータを表計算言 語を用いて開発した。セボフルレンの第一相臨床試験の 5 例について実測值対予測値の比較をした。 両者は, 麻酔開始 1 時間の $\mathrm{F}_{\mathrm{A}} / \mathrm{F}_{1}$ では $0.88 \pm 0.03$ 対 0.86 , 覚醒時間では $10.7 \pm 2.1$ 分対 11.1 分となり， よく一致した。

予測結果によると, $\mathrm{F}_{\mathrm{A}} / \mathrm{F}_{\mathrm{I}}$ の上昇は笑気に匹敵するが, $\lambda$ 組織/血液が笑気より大きいため, 肺胞 と脳の濃度に解離ができ, 脳 MAC の上昇は幾分緩やかになること, 同一の脳 MAC で維持した場 合他の吸入麻酔薬に比べ攝取量が少ないこと, 長時間麻酔での覚醒遅延がないこと, 気化器の濃度 範囲は2.5MAC 程度を上限とすると安全, などの点が示唆された。

\section{目的}

セボフルレンは笑気に近い 0.59 という血液ガ ス分配係数を持つこと ${ }^{1), 2)}$, 及び, Holaday らを 始めとするいくつかの実験的知見により ${ }^{3) ~ 5)}$ 速や かな導入と覚醒という薬動力学的性質が期待で きる. しかし, Egar ${ }^{6)}$, Lowe ${ }^{7)}$, Fukui ${ }^{8)}$ の研究 で代表されるコンピュータシミュレーションや 実測值との対応は，八ロセンなど他の吸入麻酔 薬と違って，なされておらず，明解な解説や図 式的表現(例えば $\operatorname{Egar}^{6}$ にによる $\mathrm{F}_{\mathrm{A}} / \mathrm{F}_{\mathrm{I}}$ 図)を入手 することは困難である。一方，本邦では，この 新薬はすでに臨床応用の段階であり（1986.)， 理論的シミュレーションがあると，効率の良い
臨床試験計画，結果の考察や安全な投与計画の ために有用と思われる。

ところが，投与法などについて臨床に見合つ たシミュレーションを行うには，吸入濃度一定 といった画一的・教科書的な条件を前提にする ことはできない。したがって，臨床を想定した ダイナミックな操作, 例えば, 吸入濃度やフレ ッシュガス流量レベルの変動に対し，対応が簡 単で，グラフ出力など記録が残せる実用的なシ ミュレータが第一に心要であり，第二に，的外 れの予測結果にならないことを実測值との対応 により裏付ける必要がある。

以上の観点から, 臨床的な問題解析と出力機 能を重視したシミュレータを16ビットパーソナ ルコンピュータと市販の表計算言語 (Super Calc 3 ）を用いて開発した。次いで，実デー夕（著 
9 Compartments Non-linear Model : Sevoflurane

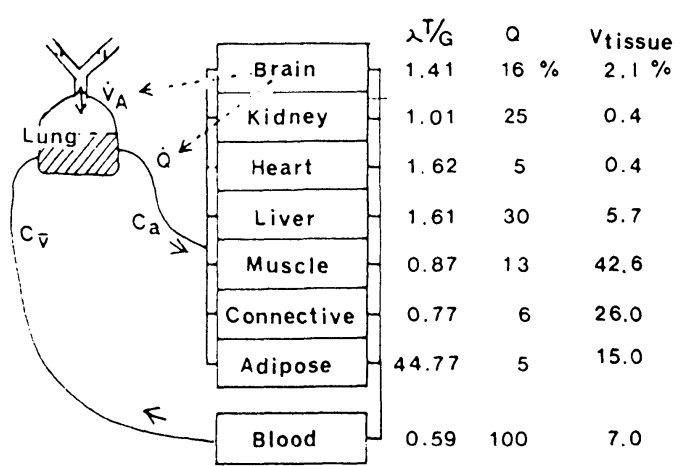

図 1 モデルの構造と主な計算式

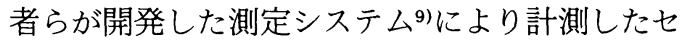
ボフルンの呼気終末值と摂取量，および，観察 した導入・覚醒時間など）と，予測值との対応 を試みた。

以上の確認を行ったのち，このシミュレータ を新薬セボフルレンについて導入・覚醒に関す る解析や, 適性投与法および気化器の具備すべ き濃度範囲について試行錯誤する目的に応用し た.

\section{方法}

コンピュータモデルの概念は，主に，閉鎖麻

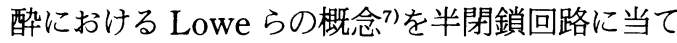
はめ, 図1のように 9 コンパートメントに表現 した。ただし，より臨床に近づけるため機能的 残気量 FRC の要素, 麻酔器の要素, 脳内濃度か ら肺胞換気量と心拍出量へのフィードバック(非 線形モデル）などを加味して，図のように式化 した。具体的には肺胞気と静脈血が麻酔ガスを 交換し，臓器による摂取を経て，新しい静脈濃 度が決定される過程を差分方程式に表現し，時 々刻々に計算を繰り返す方法でプログラミング
1) 肺胞浱度 $\mathrm{C}_{\mathrm{A}}$ 決定式 ( $\mathrm{j}$ 番目の $\mathrm{C}_{\mathrm{A}}$ )

$$
\begin{aligned}
& C_{A}(j)=\frac{\left(\dot{V}_{A}+\dot{U}\right) C_{1}+C \nabla Q+C_{A}(j-1) F R C}{\dot{V}_{A}+\lambda B / G \dot{Q}-\dot{U}+F R C} \\
& t: L_{,} \\
& \dot{U}=\dot{Q}_{N_{2} O}+Q_{a n}+\dot{V}_{O_{2}}-\dot{V}_{\mathrm{H} O}
\end{aligned}
$$

2) 麻醉器 Deliverly System の設定と吸入搌度 $C_{1}(j$ 番目) の娄 $C_{1}(j)=\frac{C_{\text {Del }} \dot{V}_{\text {Del }}+f R \cdot C_{A} \dot{V}_{A}+V_{C_{1, c}} C_{1}(j-1)}{\dot{V}_{T}-f R \cdot \dot{V}_{D}+\dot{U}+V_{C_{1, c}}}$

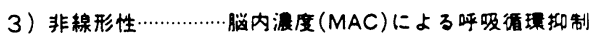
$f C O=0.82 \times M_{A B C} C_{B a i n}, f \overline{A P}=0.82 \times M_{A A C} \cdot a r$ $f \dot{V}_{A}=0.84 \times M A C_{\text {Brain }}$

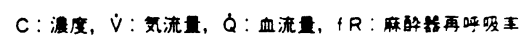

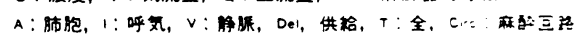

を行った。計算間隔は自由に選べるが，パーソ ナルコンピュータの不十分な記憶容量を配慮し て，0.1〜2秒間隔を基本とした.

なお, 非線形要素は各研究者の実験成 績(3),4),55,10)に基づき MAC と肺胞換気量・平均動 脈圧・心拍出量が比例すると仮定し, 臨床試験 に扔ける麻酔 60 分後のセボフルン呼気終末值 $(1.4$ $\pm 0.09 \mathrm{MAC})$, 平均血圧及び $\mathrm{PaCO}_{2}$ から, 図 1 にしめす非線形性に関する係数を決めた。

シミュレーションに用いた各麻酔ガスの基礎 データは表 1 に示した。 心拍出量・肺胞換気量 ・機能的残気量（FRC）など体格に依存するパ ラメータについては, 体重を代入すれば, 計算 できる Kleiberの $\mathrm{kg}^{3 / 4}$ の方法7)用いた。今回は 後述のセボフルレンの第一相臨床試験ボランテ イアの平均体重もしくは日本人男子の平均体重 に近いという意味で $60 \mathrm{~kg}$ 入力してシミュレー トした（表1)。表1について，MACはヒトに ついてのデータが確立されていないが，暫定的 に，当施設での第 2 相臨床試験などの成績から $1.74 \%$ に仮定した。組織/ガス分配係数 $\lambda \mathrm{T} / \mathrm{G}$ は

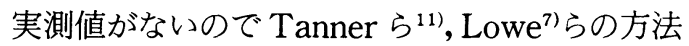


表 1 シミュレーションに使った主なパラメータの值

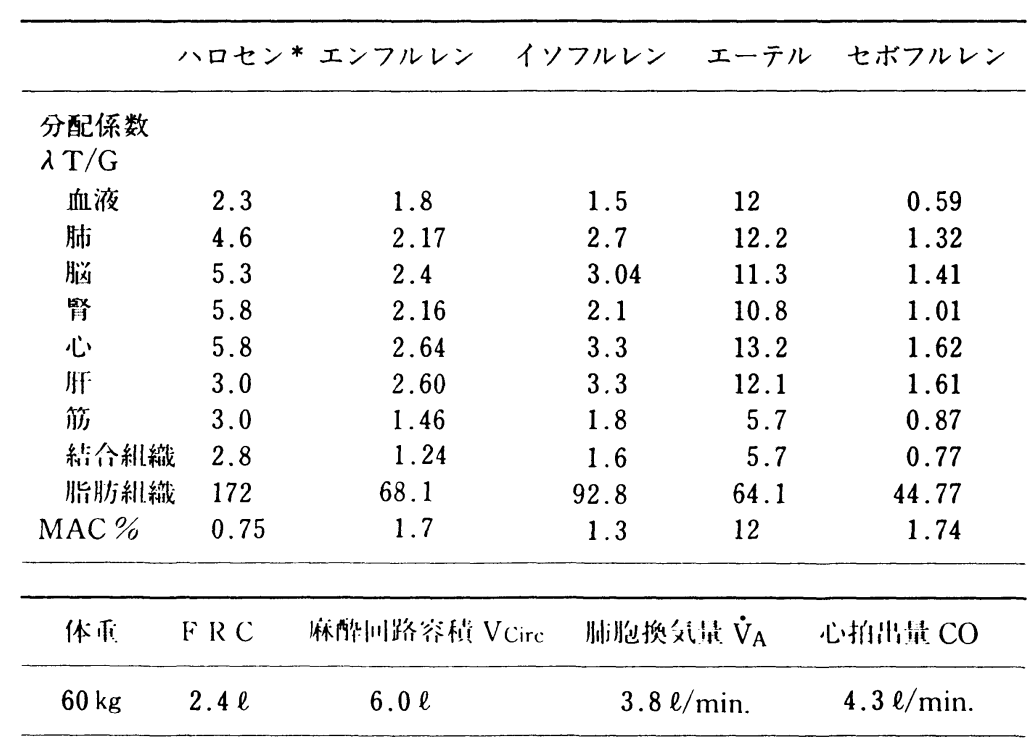

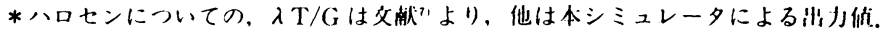
説们本父

に従って各麻酔ガスの油／ガス分配係数，水／ ガス分配係数の両者 2 (2), 及びハロセンで知られて いる各臓器分配係数から計算》で求めた。

プログラミングは, NEC 社のパーソナルコン ピュータ PC-9801上で, 表計算とそのグラフ出 力を特徴とした簡易言語 Super Calc 3 release 2 （コンピュータ・アソシエイツ，東京）を用 いて行なった。モデルの妥当性について，当施 設で行なわれたセボフルレンの第一相臨床試験 について次のような計測により得た実データを 利用して検討した。

被験者はボランテイアの男性 6 名中, 吸入濃 度の設定が他の被験者と大幅に異なる第一例を

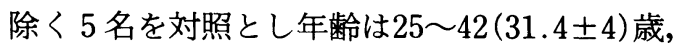

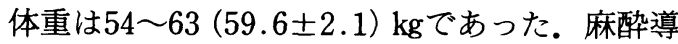
入は終末呼気サンプリングプローベ（先端は鼻 前庭に到達）を組み込んだマスクを用いてセボ フルレンのみで自発呼吸下に行ない, 吸入濃度
設定は $4 \%$ 導入 $3 \%$ 維持を目安とし， 1 時間の 麻酔中と 2 時間の覚醒過程を観察した。

麻酔回路は，開放回路（非再呼吸回路）を用 いた，新鮮ガス流量は $13 \mathrm{~L} / \mathrm{min}$ 以上とし，吸気 回路中に容積5L のリザーババックをつけて最大 吸気流量に対応できるようにした。麻酔終了時 には,このバッグを空にし, 速やかに吸入濃度 が下降するようにした．この時の呼びかけに応 答しなくなった時間12) と応答した時間 (以後, 入 眠時間，覚醒時間とする）などを測定するとと もに，次のような測定を行なった。

当施設が開発した質量分析装置を用いた時分 割測定システム9),13)を用いて呼気終末麻酔ガス濃 度や麻酔ガス摂取量など図 2 に示すパラメー夕 について実測した。換気量の測定は，リニアラ イズした electric wright respirometer ${ }^{13)} て ゙$ 行い, 実験後水シールド型スパイロメータ（フクダ連 続記録呼気流量計 CR-20，福田産業 Co., 東京） 


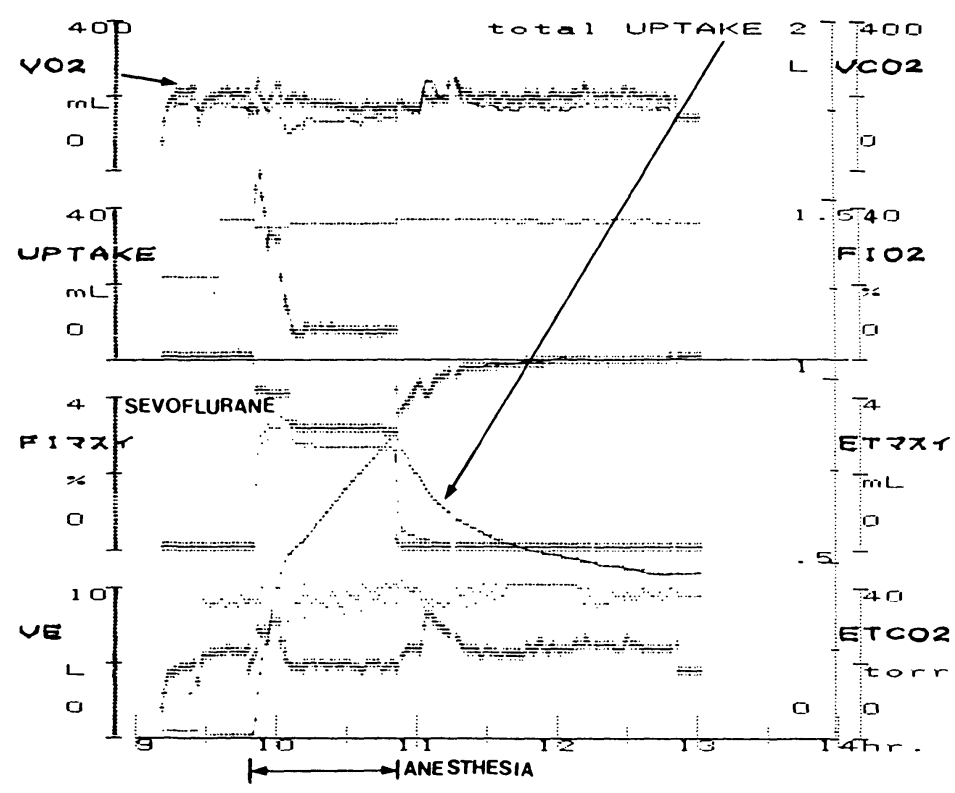

図 2 画面表示された実測データ群

データはシミュレータにリンク可.

により再較正した.質量分析装置(Perkin Elmer MGA-1100）は毎実験前製鉄化学社製基準ガス を用いて調整したが, 今回の報告する成績には， その後の同メーカー及び当施設でのガスクロマ トグラフによる評価に基づいた補正值を用いた。

以上の測定で得られた 3 種の実データ（終末 呼気麻酔ガス濃度・毎分の麻酔ガス摄取量・入 眠および覚醒時間）とモデルの予測值とを比較 し，モデルの妥当性を検討した。なお，シミュ レーションモデルの入眠と覚醒の基準としては Stoeling ら ${ }^{12)}$ の MACawake を脳内濃度に当て はめた Lowe ら7の0.4MACを用いた。

以上モデルの妥当性を検討した後, 応用とし て, セボフルレンの導入については, $\mathrm{F}_{\mathrm{A}} / \mathrm{F}_{\mathrm{I}}$ の作 図を行った。この際, セカンドガス効果および 他の吸入麻酔薬との関係も考慮した，覚醒につ いては, 各臟器を1.3MACで飽和させた後 (具
体的には12日間の麻酔をシミュレート), 覚醒さ せた場合の脳内濃度の時間経過を他の吸入麻酔 薬と比較した。

次に, セボフルレン単独で導入・維持を行な う場合を例に取り，適正と思われる投与例を試 行錯誤した。また，この試行錯誤から，安全性 を考慮した麻酔法と気化器の出力濃度範囲につ いて検討した。

\section{結 果}

図 2 はベッドサイドターミナルから得られた, 今回の実測データのグラフィック表示例である. 吸入麻酔薬濃度とこれに対応する呼気終末值, 毎分あたり麻酔ガスの捸取量とその積算量など を示している.この実データのうち全実験区間 連続測定に成功した 2 例から吸入濃度の值をモ デルにリンクして得られた結果と実測呼気終末 

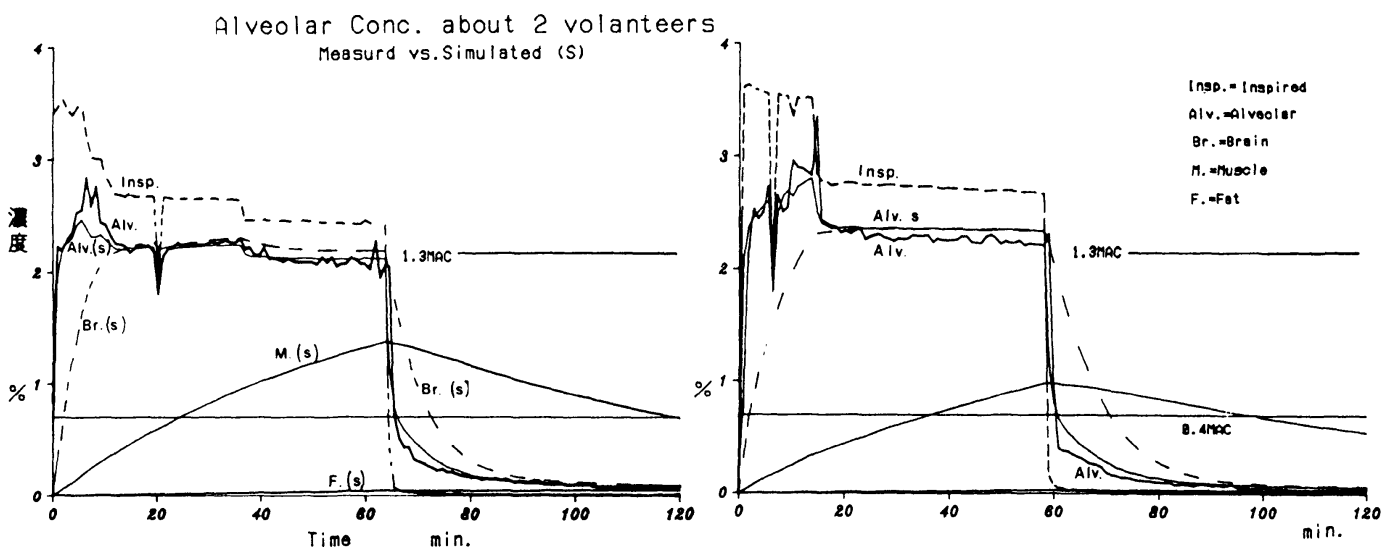

図 3 同一吸入濃度に対する実測対予測肺胞濃度

Insp., Alv.は実測.(S) はすべてシミュレーション值で実測のInsp. (吸入濃度)を非線形 モデルに代入して得たもの. 非グラフとコメントの全んどの部分をこのシミュレータ

により作成, 以下のグラフも同様。

Cumulative Uptake of Each Anesthet ic

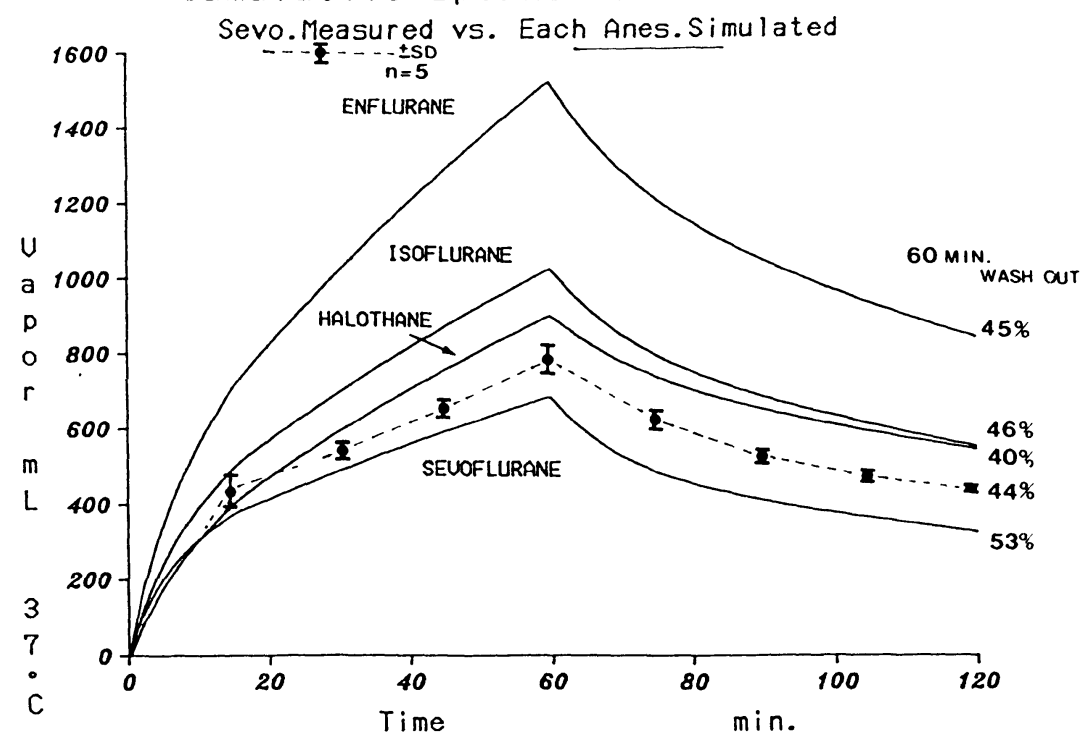

図 4 セボフルレン皘算量に関する実測值と予測值.

非線形モデル。他の麻酔薬は同一吸入 MACに換算して予測.

值との対応を図 3 に示した. $F_{A} / F_{1}$ の実測予測值 は，麻酔 $5 ， 10 ， 60$ 分につき，それぞれ，0.75土 0.01 対 $0.73,0.85 \pm 0.02$ 対 $0.80,0.88 \pm 0.03$ 対 0.86 であった. 60 分の呼気終末值の実測対予測 值では, 吸入濃度 $2.66 \pm 0.22 \%$ に対し $2.34 \pm$
$0.16 \%$ 対 $2.31 \%$ であった。

実測の積算セボフルレン捸取量の時間経過と 麻酔終了後60分における呼気中排泄率について， 5 名の平均吸入濃度と体重からの予測値と対応 させて図 4 に示した。また，比較のため，同一 
表 2 入眠と覚醒時間についてシミュレーション及び実測結果

\begin{tabular}{|c|c|c|c|}
\hline & 人肘!结洲 min. & 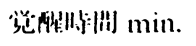 & \\
\hline 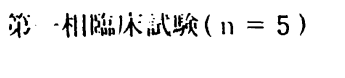 & $1.8 \pm 0.1$ & $10.7 \pm 2.1$ & 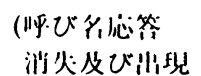 \\
\hline コンピュータモデル & & & $\begin{array}{c}\text { (0.4 MACを.1: } \\
\text { トする時洲) }\end{array}$ \\
\hline 綵形モデル* & 2.1 & 9.0 & \\
\hline \multicolumn{4}{|l|}{ 非線形モデル** } \\
\hline \multicolumn{4}{|l|}{ 新鮮ガス流显*** } \\
\hline$\infty$ (蛅休試騃と间条件) & 2.2 & 11.1 & \\
\hline $10 \mathrm{l} / \mathrm{min}$ & 2.5 & 11.9 & \\
\hline 6 & 2.9 & 12.3 & \\
\hline 3 & 4.0 & 13.8 & \\
\hline$\infty$ 笑氛 & 1.4 & 6.8 & \\
\hline $70 \%$ 並用) & & & \\
\hline
\end{tabular}

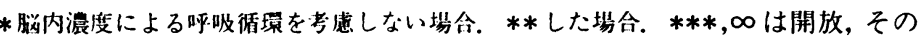
他は半䦥鎖回路。

FA/FI of each anesthetic $\mathrm{FI}=1 \mathrm{MAC}$, $\quad \cdots+\mathrm{N} 2078 \%$

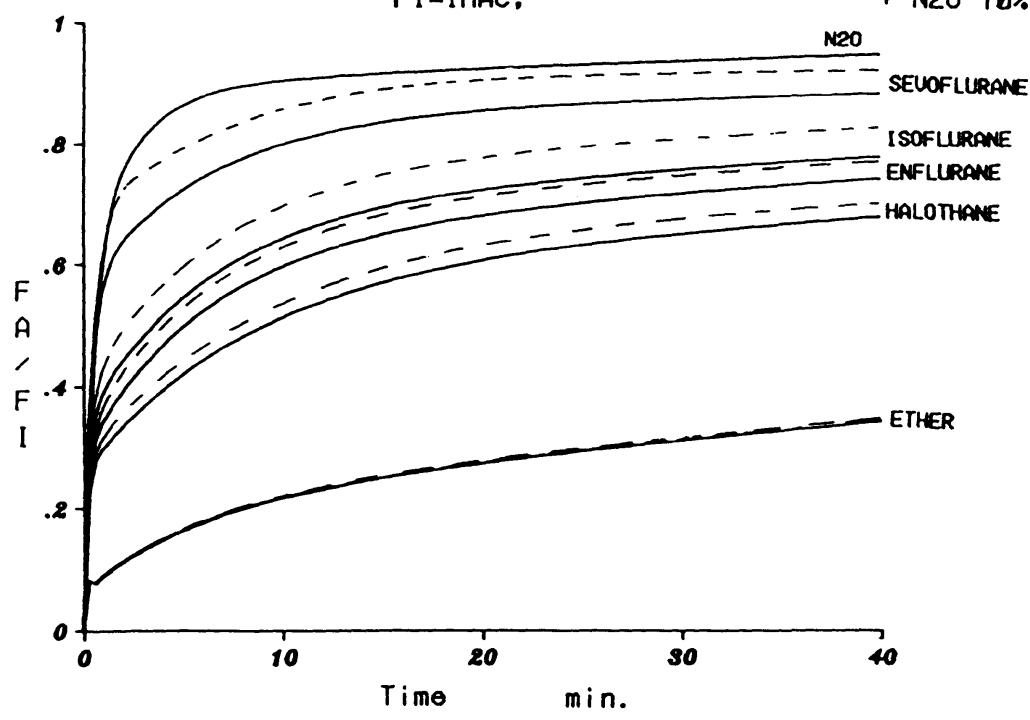

図 5 セボフルレンの $F_{A} / F_{1}$ とセカンドガス効果：他の吸入麻酔薬との比較 線形モデルに吸入濃度 $1 \mathrm{MAC}$ の麻酔を施行した場合の シミュレーション結果．点線は笑気70\%を併用した場合。

吸入 MACにおける他の麻酔薬についても併記

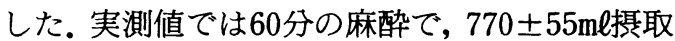

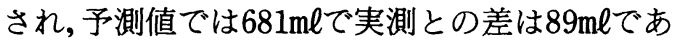
った。呼気中排泄率では，それぞれ $44 \%$ と $53 \%$
で実測值の方が少なかった。

各被験者の入眠時間と覚醒時間と，対応する 線形及び非線形両モデルの予測值を表 2 に示し た．臨床試験に相当する開放麻酔回路における 


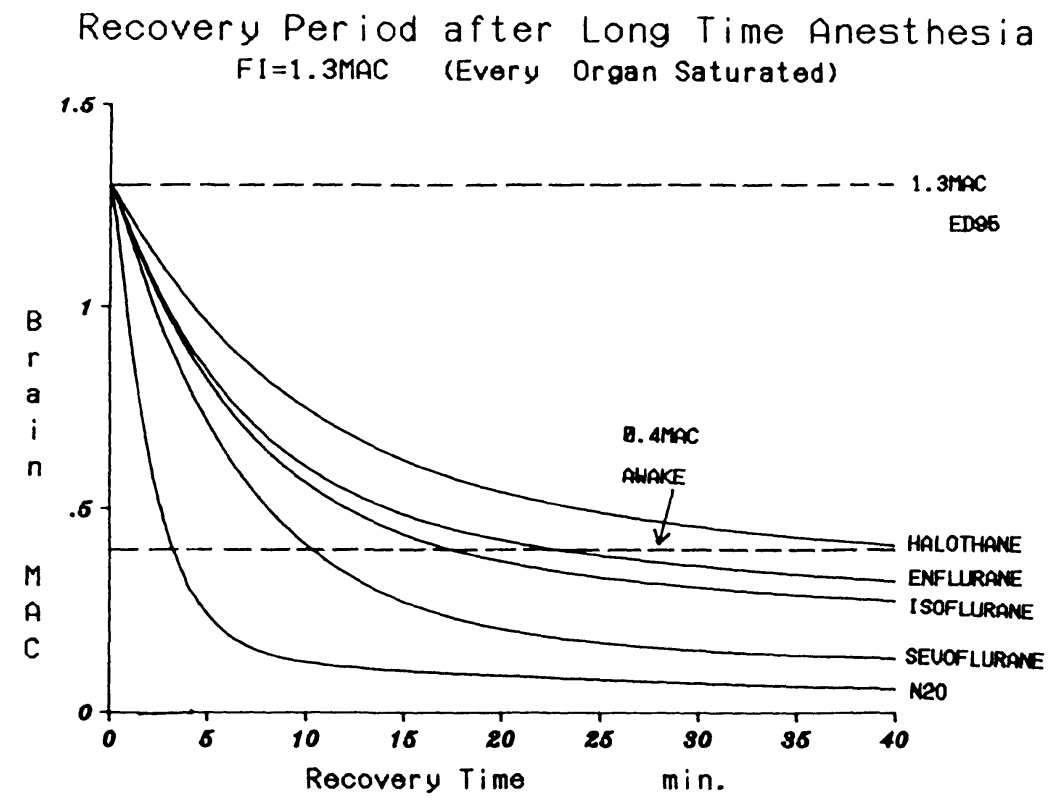

図 6 覚醒時間の予測。

線形モデル。

非線形モデルの入眠時間については実測値との 差が+0.4分で，覚醒時間については+0.4分で あることが読み取れる。なお, 麻酔器の新鮮ガ ス流量を減じると表 2 のように延長し, 笑気併 用では短縮した。

以下，このモデルから得られた出力を示す。 非線形モデルを用いて, $\mathrm{F}_{\mathrm{A}} / \mathrm{F}_{1}$ を各麻酔ガスと 比較した結果をセカンドガス効果と共に図 5 に 示した. 図 6 は各臓器を1.3MACで飽和させた 後 (長時間麻酔) の脳内のセボフルレン濃度を 他の吸入麻酔薬と比較して出力したものである. 笑気>セボフルレン>イソフルレン>ハロセン の順に覚醒が速やかで，笑気とセボフルレンの 場合 10.5 分で0.4MACを下回った後も勾配が 急, という特徵が分かる。 また，1時間の肺胞 濃度1.3MAC 麻酔 (表 2 における線形モデルが これに相当）では，9分で覚醒するが，その差
は1.5分とわずかだった.ちなみに，ハロセンの 場合, 差は27.5分であった。

単独で導入・維持を行なう条件で, 導入後早 期に肺胞濃度を立上げ一定に保つことを目標に して，試行錯誤した投与例を図 7 に示した. 2 MAC 緩速導入で，10分後より1.5MACで維持 する麻酔法では, 脳内の麻酔ガス濃度は1.5分で MACawake レベルを通過し，そのまま維持する と, 肺胞換気量 $\mathrm{V}_{\mathrm{A}}$ や心拍出量 $\mathrm{CO}$ が脳内の麻酔 ガス濃度に影響されないとした線形モデルで 6.5 分, 影響される非線形モデルでは7.2分で $1 \mathrm{MAC}$ を越え挿管・術操作に対応できる脳内濃度もし くは麻酔深度に達し，10分程で手術可能と思わ れる1.3MAC の目標に近づいて安定することが 示されている.

一方, 図 7 右は $3 \mathrm{MAC}$ の高濃度に放置した 場合をシミュレートしている.脳内濃度は 3.5 分 


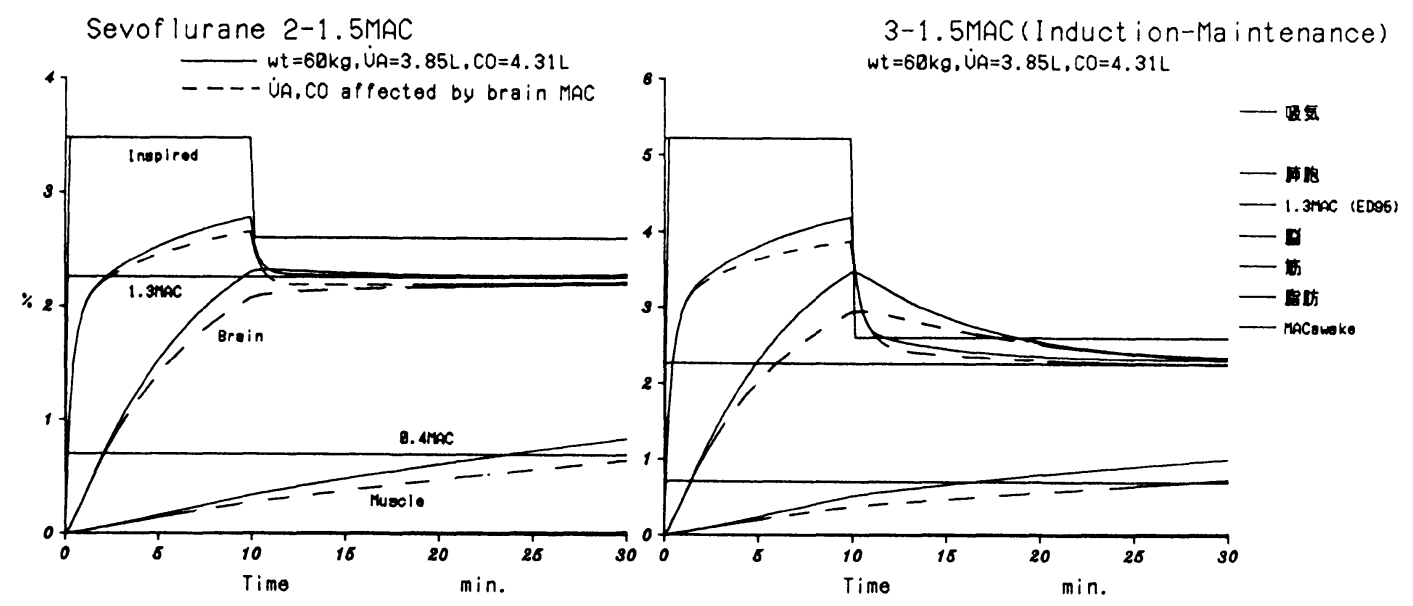

図 7 セボフルレン単独 $2 M A C$ 及び $3 M A C$ 緩速導入の例. 非線形モデル。

で1 MAC を越え，4.6及び5.7分で予定の 1 . 3MACを越え linear model では10分で風間4), 今村ら ${ }^{10)}$ がイヌで示した血圧低下などからみた安 全な使用範囲の上限に近い $2 \mathrm{MAC}$ の脳内濃度に 達してしまうことが読み取れる。

\section{考察}

実測値との対応

麻酔薬の実測呼気終末濃度と, 同一吸入濃度 における肺胞濃度の予測值が, 一過性の摇れに 至るまで，よく追随することが明らかである。

麻酔ガス捸取量積算値についても, 実測值と 相似の時間経過をとる, ただ量的には 1 時間值 では実測値の方が多く, モデルの不備, 実測值 の誤差などから由来する理由の他に，代謝によ る捸取量増大など種々な要因が考えられ, 今後 検討すべき対照と思われる，ただ，他の麻酔ガ スで同一 MACの麻酔をシミュレートすると， 麻酔ガス摂取量は, セボフルレン<イソフルレ ン<八ロセン<<エンフルレンとなり（図 4), 最もセボフルレンが少ない結果となり, 大略的
には，捸取量が少ないと言う性質を実測值が裏 付けていると考える.

実測入眠時間と覚醒時間はモデルの脳内濃度 が0.4MACを上下する時間と近似しており，モ デルの0.4MACawake の基準 ${ }^{12}$ が入眠と覚醒の 示標になることが実測值との対応から分かった。

また，使った新鮮ガス流量と，併用した笑気 により, 導入覚醒の速度が異なることがシミュ レーションから分かり, 実験や臨床データを評 価するに当たり，この点を厳密に点検すべきと 考える。

以上, 呼気終末值・摄取量・導入及び覚醒時 間について検討したように, 細部の違いはある ものの，作成したコンピュータモデルは実測デ ータとよく対応すると思われ，これを用いたシ ミュレーションからは，実測では得られない脳 や筋肉内の濃度を推測することができるので, 臨床的な投与法に関する試行錯誤または事前事

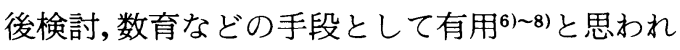
る.

以下，モデルを用いた検討内容である. 


\section{導入と覚醒}

導入についてセボフルレンを他の麻酔ガスと 比較してみると, $\mathrm{F}_{\mathrm{A}} / \mathrm{F}_{\mathrm{I}}$ の立ち上がりの早さでは, イソフルレン，エンフルレンより上で笑気に近 い位置づけとなり（図 5 ), 実測定の入眠時間で も1.82分と速やかであることが確認できた（表 2 ).さらに検討を加える場合, 導入は脳内濃度 に依存するという理由で, $\mathrm{F}_{\mathrm{Brain}} / \mathrm{F}_{1}$ を検討すべき である. 図3，6に示した通り， $F_{B r a i n} / F_{1}$ の上昇は $F_{A} / F_{1}$ で期待した程早くなく,笑気に比較して緩 やかである。

このように, 脳内濃度の上昇が遅れるのが, 笑気との最も大きな差であり，これは表 1 に示 した著者らの計算値による $\lambda^{\text {Brain } / \text { Blood が笑気 } 1.1}$ の 2 倍以上の 2.39 であり，笑気に比較して組織 に溶け易い（ただし，八ロセンなど他の揮発性 吸入麻酔薬と同程度）というのがその理由と思 われる。

例えば，2MAC 導入の投与例（図 7 ）では, 肺胞濃度が脳内濃度と解離するため, 肺胞濃度 が所定の MAC に到達しても挿管などの操作に 適する脳内濃度に達していないことがしめされ ている，ただ，笑気の場合，0.8MAC 程度の吸 入濃度が限界だが, セボフルレンは吸入濃度を 上げて，脳内濃度の速やかな上昇の目的を達成 することができる。この $2 \mathrm{MAC}$ 投与例に示した ように, 予定肺胞濃度が達成された後, 脳内濃 度の経過を考慮して待つことを心掛けると, セ ボフルレンのみでも緩速導入が可能と言うこと が示唆される。

覚醒については, 他の吸入麻酔薬と比較する と(図 6)，0.4MAC を下回るのが速やかで，そ の後も勾配が急であり, 覚醒が特徵的な明解さ で起こることが示唆され, 臨床知見ともよく一 致している.
また，長時間麻酔での覚醒遅延が僅少と言う 特徵が示唆される。

気化器に要求される濃度範囲

図 6で示すように2MAC (3.48\%) を 5 ～ 7 分維持すれば脳内濃度は1MACを越えるので, 気化器も $2 \sim 2.5 \mathrm{MAC}$ 程度が出力できれば実用 になる，また，図 3 のように3MAC (5.22\%) に吸入濃度を設定した場合 2 分で予定 MACを 越えてしまい導入などが速やかというこの麻酔 ガスの利点よりも，不注意によるミスを誘いや すいという欠点が表面化すると思われる。ただ し，この問題をよくわきまえた経験を積んだ麻 酔医が 2 分以内を目安に速やかに維持濃度に移 すことができれば，より急速な導入が可能だと 思われる。しかし，不注意ミスを防ぐ意味で， 出力が $2.5 \mathrm{MAC}(4.35 \%)$ 程度でロックされる 機構をもった気化器にすれば，吸入濃度自身が 安全範囲を越えることがなくなってしまうので, この調節性のよい麻酔ガスを安全に臨床に導入 する一つの方法と思われる。

モデルについて

これまで, Tanner ${ }^{11)}$ の 3 コンパートメントモ デルや Brandom ${ }^{14)}$ のモデルなど, 電卓やパーソ ナルコンピュータ用に作られたモデルは理論式 を基にしているので, 吸入濃度の変化や以下に 述べる臨床的問題には対応が難しい.

一方，多コンパートメントモデルの概念は， 麻酔や手術による各臓器血流分布のシフト, 臓 器摘出の影響など, 臨床で起こりうる各種の問 題解析に有利と思われ, Lowe ら Fukui 及び Smith ${ }^{8)}$ モデルはこの概念に入る。しかし，ア ナログやハイブリッド計算機など巨大なシステ ムの制約をうけ，実用的とは思われない。 
同タイプに属する著者らの表計算言語を用い る方法には，吸入濃度や非線形性の設定に対す る自由度，計測システムとのリンク，パーソナ ルコンピュータ上での作動, などの利点があり, 今後, 臨床麻酔を支援する実用的シミュレータ として発展する可能性がある，著者らの使用感 としては, 予測機能のみでなく, 結果の出力機 能や記録性が，相当程度この種のシステムの実 用性を左右すると思われた。

\section{結 論}

表計算言語を用いて吸入麻酔薬薬動力学シミ ュレータを作成した。セボフルレンについて， 呼気終末值・摂取量・導入覚醒時間について実 測值と比較した結果，細部には考慮すべき点が 多いが，大略的には良い一致を見た。また，捸 取量は少ないと予測される。

セボフルレンについてのシミュレーションで は, $\mathrm{F}_{\mathrm{A}} / \mathrm{F}_{1}$ の上昇は笑気についで速いが, 組織 / 血液分配係数が笑気の 2 倍程度と予測されるた め, 肺胞と脳の濃度に解離ができ, 脳 MACの 上昇は幾分緩やかになるのが特徵が明らかであ る、したがって，笑気併用の場合は，導入覚醒 の速やかさが強調される。

気化器の濃度範囲は2.5MAC (4.35\%) 程度 を上限とすると，何らかのミスで安全域を越え ることがなくなり，この調節性の良い麻酔薬を 安全に臨床に導入する方法として推奨できる.

本研究の一部は, 第 5 回日本臨床麻酔学会で 報告した。

本研究の臨床試験部分に関して, 御協力いた だいた教室の加藤清司, 風間富栄, 増田美知子 の諸氏に感謝いたします。

\section{参考文献}

1) Walium RF, Regan BM, Napoli MD, et al. : Sevoflurane; A new inhalation anesthetic agent. Anesthesia and Analgesia 54:758 765, 1975

2 ）丸石中央研究所報, 1986

3) Holady DA, Smith FR: Clinical characteristics and biotransformation of sevoflurane in healthy human volunteers. Anesthesiology $54: 100 \sim 106,1981$

4 ）風間富栄, 今村 聡, 由良正幸, 他：新しい吸入麻酔薬 Sevoflurane と Halothane, Isoflurane の MAC 及び導 入時間の比較. 麻酔 $34: \mathrm{S} 75,1985$

5 ) 池田和之, 佐藤一雄, 加藤清司, 他 : 新吸入麻酔薬セボ フルレンの臨床第 1 相試験に関する知見. 麻酔 $35: \mathrm{S} 91$, 1986

6 ) Egar El : A mathematical model of uptake and distribution of anesthetic agents, Uptake and Distribution of Anesthetic Agents. Edited by EM Papper, et al., New York, McGraw-Hill, 1963, 77 88

7 ) Lowe HJ, Ernst EA: The Quntitative Practice of Anesthesia. Baltimore: Williams and Wilkins, 1981

8 ) Fukui $Y$, Smith $T$ : Interaction among Ventilation, the Circulation, and the Uptake and Distribution of Halothane-Use of Hybrid computer multiple model. Anesthesiology $54: 107 \sim 124,1981$

9 ) 三条芳光, 池田和之：麻酔器安全モニタリングの効果と システム的意義. 医器学 $55: 505 \sim 512,1985$

10）今村 聡, 風間富栄, 由良正幸, 他: 吸入麻酔薬 Sevoflurane, Halothane, Isoflurane の循環動態及び心筋の Epinephrine 感受性. 麻酔34：S409，1985

11) Tanner G. Pharmacokinetics of Inhalation Anesthetics : A three compartmen linear model : Anesthesia and Analgesia61: 410 581, 1982

12) Stoeling RK, Longnecker DE, Egar EI : Minimum alveolar concentration in man on awaking from metoxy flurane, halothane, ether and fluoxene anesthesia : MACawake. Anesthesiology33 : 5, 1970

13）三条芳光：呼気ガス監視のための時分割質量分析装置. 尾山力, 池田和之編, 麻酔集中治療とコンピュー夕. 克 誠堂, 東京, 1984，49〜65頁

14) Brandom BW, Brandom RB, Cook DR: Uptake and distribution of halothane in infants : In vibo measurements and computer simulations. Anesth Analg 62 ; p404 410, 1983

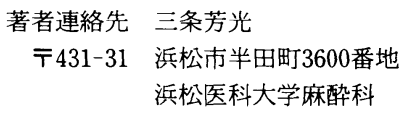




\title{
A Pharmacokinetics Simulator and Its Aplication to the Analysis of New Anesthetic; Sevoflurane
}

\author{
Yoshimitsu SANJO, Kazuyuki IKEDA \\ Department of Anesthesiology, Hamamatsu University School of Medicine
}

We developed 9-compartments pharmacokinetics simulator using commercially available spread sheet software. The main features are type-less input of monitoring data in operating room and graphic plotting with $\mathrm{X}-\mathrm{Y}$ plotter. We compared the measured values in sevoflurane's clinical phase study with predicted values from our simulator. Measured vs. predicted mean values from 5 volunteers were as following. About $F_{A} / F_{I}$ at 1 hour after the start of anesthesia it was $0.88 \mathrm{vs}, 0.86$ and about the response time to verbal comands it was 10.7 vs. $11.1 \mathrm{~min}$. Both parameters correlated well.

From our simulations we predicted followings. $F_{A} / F_{I}$ rise rapidly nealy like $\mathrm{N}_{2} \mathrm{O}$, but the brain concentration rise much slower than $\mathrm{N}_{2} \mathrm{O}$. The reason comes from the difference between alveolar and brain concentration introduced by the different $\lambda$ Tissue/Gas of both anesthetics. Sevoflurane's vaporiser shoud not be setting on the level over 2.5 MAC for its safty and effective usage in clinical stage.

The Journal of Japan Society for Clinical Anesthesia Vol. 7 No. 1,1987 